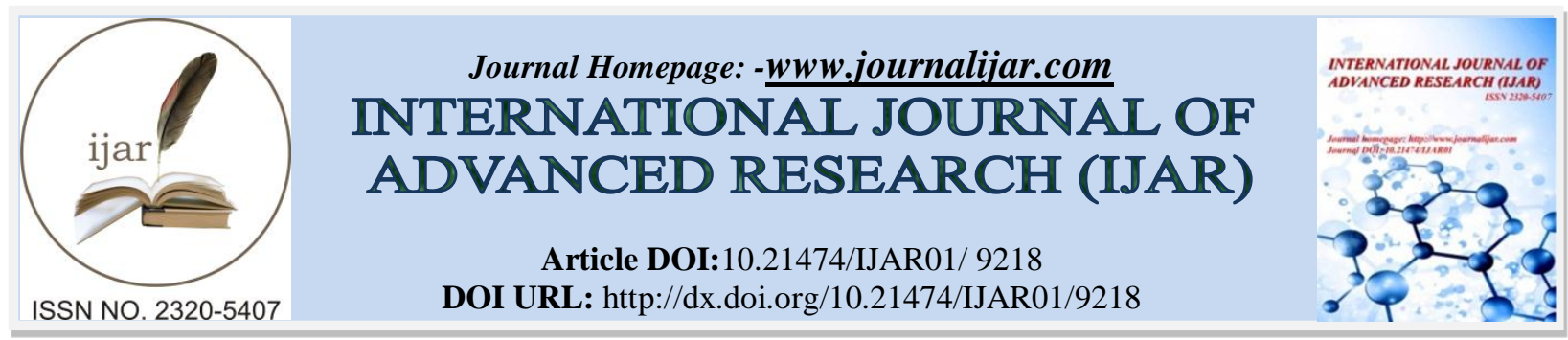

RESEARCH ARTICLE

\title{
BASIC EDUCATIONAL MANAGEMENT BY REGENCY/CITY GOVERNMENTS IN MALUKU.
}

Yohanes Pattinasarany ${ }^{1}$, Andi Pangerang Moenta ${ }^{2}$, Syamsul Bachri ${ }^{2}$ and Yunus Wahid ${ }^{2}$.

1. Faculty of Law Univesity of Pattimura, Maluku, Indonesia.

2. Faculty of Law Univesity of Hasanuddin, Sulawesi, Indonesia.

\section{Manuscript Info}

Manuscript History

Received: 05 April 2019

Final Accepted: 07 May 2019

Published: June 2019

Key words:-

Responsibility, Management of Basic Education.

\begin{abstract}
This Research aims to find out the sense of responsibility for basic education management by Regency/City governments in Maluku. The Research method used in this study is Empirical Law.

The results of the study indicate that the form of responsibility for managing basic education by the Regency/City Government in Maluku is regulating or forming regional legal rules and managing or serving the basic education needs. The responsibility is intended as a manifestation of the implementation of state functions as a provider and regulator. However, the Regency/City Government in Maluku has not yet implemented the responsibility of managing or serving the basic education management needs according to the minimum standard of basic education services. Also the Regency/City Government have not carried out the responsibility of regulating or establishing or stipulating regional legal regulations for both regional regulations and regional head regulations. Even though the consequences and submission of Basic Education affairs to the head of the Regency/City area require the Regency/City Governments in Maluku to carry out the intended responsibilities for direct and control and build a quality basic education in Maluku.
\end{abstract}

Copy Right, IJAR, 2019,. All rights reserved.

\section{Introduction:-}

Basic education is a level of education that underlies the intelligence, skills, and personality of students to prepare themselves for further education or living in society. Through the learning process at the basic education level, every citizen can develop their potential through the process of learning to read, write and count, which ultimately frees themselves from the most fundamental shackles, namely illiteracy, ignorance, backwardness, weakness, backwardness, and changing ways of thinking, behaving, and acting.

The learning process in basic education held in elementary schools or Madrasah Ibtidayah for 6 years and continued in junior high school or Madrassa Tsanawiyah for 3 years as a single 9-year basic education. Primary school is one form of formal education unit that organizes general education. Madrasah Ibtidayah is one form of formal education unit that organizes general education with the peculiarities of Islam. Junior high school education is a unit that organizes public education as a continuation of the elementary school or Madrasah Ibtidaiyah. While Madrassas Tsanawiyah an educational unit that organizes general education to the particularities of Islam as a continuation of the elementary school or Madrasah Ibtidayah. 
Constitutionally, article 31 section (2) of the Constitution of the Republic of Indonesia stipulates that every citizen is required to attend basic education. The regulation is regulated further in article 6 section (1) of Law No. 20 of 2003 concerning the Education System (hereinafter briefly Law No. 20 of 2003) that every citizen aged seven to fifteen is required to attend basic education. The consequence of the regulation meant that every Indonesian citizen, including in Maluku, as one of the Provinces in Indonesia must attend basic education. Even the State has programmed compulsory education at a minimum at the level of basic education that must be followed by all Indonesian citizens.

Obligations of citizens in question must be followed by the State's obligation to carry out the actions of government in the field of basic education to fulfill basic education for every citizen. To bring closer and enhance the implementation of government actions in the field of basic education to every Indonesian citizen in areas including in Maluku, the central government surrenders the matter of basic education to the regency/city area which is legally regulated in article 50 section (5) Law No. 2003 concerning the National Education System, in conjunction with article 12 letter a along with Attachment to Law No. 23 of 2014 concerning Regional Government. The referral of the basic education affairs to the regency/city area is also an act of the State to expand equal opportunity to citizens to obtain good basic education services.

The consequence of the devolution of basic education matters raises the responsibility of the regency/city government including in the regions in Maluku managing the affairs of basic education as an obligation to fulfill basic education needs for all citizens in each region.

There is a responsibility from a state institution or state organizing body due to the giving or surrender of authority, rights or obligations to carry out government duties, as stated by Suwoto Mulyosudarmono, that responsibility arises because of the surrender or giving or delegation of power. (Suwoto Mulyosudarmono, 1990). Responsibility is the condition of having to bear everything (if anything happens may be prosecuted, blamed, prosecuted, etc.) (Indonesian Language Dictionary). Consequently from the devolution of basic education matters to the regency/city including in Maluku, the regency/city government in Maluku bear responsibility for carrying out such responsibilities even responsible for the consequences of carrying out these responsibilities.

The existence of regency/city governments as an actor in carrying out actions to manage basic education in Maluku without relying on the central government. For this reason, the problem in this writing is how is the responsibility of the regency/city government managing basic education in Maluku?

\section{Research Methodology:-}

In accordance with the substance of the problem under study, this type of research is empirical legal research. Based on the type of research referred to, the data obtained through interviews, direct observations at the study sites which included the area of Ambon City, Central Maluku Regency, and the Aru Islands Regency. The three regions represent 11 regencies/cities in Maluku Province. Data sources used include primary and secondary data. Primary data is obtained directly from the location of the study both through interviews and observations. While secondary data is obtained through the study of documents on primary and secondary legal materials. The data obtained were analyzed to get answers to the problems under study and then draw conclusions.

\section{Results And Discussion:- \\ General Description of Maluku Region}

Maluku Province was formed by Law No. 20 of 1958 concerning the Establishment of Emergency Law No. 20 of 1957 concerning the Establishment of Maluku Level I Self-Reliance Area (State Gazette of 1957 No. 79) as Law. Although historically, Maluku Province as part of the 8 oldest Provinces in Indonesia has existed since August 19, 1945 when the Preparatory Committee for Indonesian Independence conducted the second session with the inauguration agenda of Ir. Soekarno and Drs. Mohammad Hatta as President and Vice President of the Republic of Indonesia and the establishment of the Central Indonesian National Committee as a temporary parliament. However, in 1949 there was a change in the form of an Indonesian unitary state into a Federal State so that the territory of the Indonesian unitary state was divided into 3 (three) states. This led to the existence of 8 Provinces, including Maluku, which were divided into states. However, when the form of the Indonesian State was changed back into a unitary state, in 1957 the Moluccas were re-established as Provinces and in 1999, Maluku Province was divided into 2 (two) Provinces namely, Maluku Province and North Maluku Province. 
Maluku is one of the provinces in Indonesia that has the characteristics of islands with a number of islands of less than 1,450 islands with $92.4 \%$ of the sea area, and $7.6 \%$ of the land area, with details of $527,171 \mathrm{~km}^{2}$ of sea area and $54,185 \mathrm{~km}^{2}$ of land area land, The total area of Maluku Province is $581,376 \mathrm{~km}^{2}$. The vast and not comparable condition of Maluku Province's sea area caused development efforts to be a problem because of the gap due to the too wide range of inter-island control, between sub-districts, between sub-districts and regencies, between regencies and provinces, due to the separation of islands (land) by the vast sea. Such conditions distinguish Maluku Province from other provinces in general in Indonesia.

Geographically, the territory of Maluku Province is located between $2^{\circ} 30-9^{\circ}$ South Latitude and $124^{\circ}-136^{\circ}$ East Longitude, which borders the north bordering the spooky sea, south of the Indonesian sea and the Arafura sea, to the east bordering Papua Province, and to the west it borders the Sulawesi sea.

Maluku Province has its capital in Ambon City, and the Maluku Province region is divided into 9 (nine) Regencies and 2 (two) Cities, namely (1) Ambon city, Tual city, Maluku Tengah Regency, Buru Regency, Buru Selatan Regency, Seram Bagian Barat Regency, Seram Bagian Timur Regency, Maluku Tenggara Regency, Maluku Tenggara Barat Regency, Maluku Barat Daya Regency, and Aru Islands Regency. In 11 regencies/cities in Maluku Province there are 118 Sub-districts, and 1,198 villages and 33 urban villages.

The population in Maluku Province in 2018 is approximately 1,715,548 people. Of the total population of Maluku, the human development index in Maluku Province in 2018 is ranked 25 out of 34 provinces in Indonesia with an index of 68.19, the highest index is 80.06. (Central Statistics Agency, 2018). One of the human development indices in Maluku Province is determined by the existence of quality education. Nationally, the quality of education in Maluku Province is still in the order of 27 out of 34 provinces. (Maluku Provincial Planning Agency, 2018), with the level of education participation in Maluku Province 2017/2018 Academic Year shown in the table below:

Table 1:-Education in Maluku

\begin{tabular}{|l|l|c|c|c|c|}
\hline No. & \multicolumn{1}{|c|}{ Regency/City } & $\mathbf{7 - 1 2}$ & $\mathbf{1 3 - 1 5}$ & $\mathbf{1 6 - 1 8}$ & $\mathbf{1 9 - 2 4}$ \\
\hline 1. & A m b o n & 32,32 & 14,35 & 16,41 & 36,92 \\
\hline 2. & Maluku Tengah & 38,57 & 20,57 & 15,99 & 24,87 \\
\hline 3. & Aru Islands & 43,25 & 18,79 & 15,03 & 22,93 \\
\hline
\end{tabular}

Source: Maluku Province Statistics Agency in 2018

The table above shows that the higher the age, the lower or the decrease in school enrollment rates. This should be a concern of the central government to increase the enrollment rate (aged 19-24 years) and the provincial government to increase school enrollment rates for secondary education (ages 16-18 years) and regencies/cities to increase the level of school enrollment basic education (ages 7-15 years) to increase education participation in a unified national education system.

Regency/city governments has responsibility to increase school enrollment rates at the basic education level, because basic education is the foundation that is a prerequisite for continuing to secondary and tertiary education. Through the actions of government such as the provision of school facilities and infrastructure at the basic education level corresponding national standards uniformly throughout the territory of the administrative rule that does not make it difficult for residents to reach basic education services, perform equalization of teachers and education personnel according to national standard of education between school and did not resulting in differences in quality between schools, and providing funding to finance the need for basic education so that citizens can attend basic education and even be exempt from their tuition fees.

Through the implementation of these responsibilities it will increase school enrollment rates and improve the quality of basic education in Maluku as a consequence of the transfer of management of basic education to the Regencies/cities in Maluku. Submission of government affairs to the regions accompanied by the transfer of finance, infrastructure, and human resources in accordance with the authority given. (Agussalim Andi Gadjong, 2007). Therefore, the regency/city government has the responsibility of carrying out government actions in the field of basic education, both concerning the provision of facilities and infrastructure, human resources and financial resources. 


\section{Form of Responsibility for Basic Education Management by Local Government.}

Giving responsibility to the regency/city government in Maluku for managing basic education is a new stick for the implementation of basic education, which was the responsibility of implementing it to the central government, as said by Chaniago that the granting of authority to the regional government to administer education is a new stick for the implementation of education, which was previously the authority to administer education to the central government and is now in the hands of the regional government. (Diding Nurdin, 2015). The provision of such responsibilities makes the bureaucracy management of basic education affairs more concise and opens opportunities for regency/city governments in Maluku to carry out government actions in the field of basic education in accordance with the conditions and needs of community members in the area.

Therefore, the regency/city government in Maluku obliges to carry out government actions in the field of basic education to various resources as mentioned to support the implementation of basic education in each region as an effort to bring the implementation of government tasks in the field of basic education closer to citizen's community in the area. The existence of regency/city governments in Maluku is the main actor in the implementation of government tasks in the field of basic education according to their own needs, initiatives and aspirations without being ordered by the central government, as a consequence of giving autonomy to the regions to organize and manage their own government affairs and interests society. Regional autonomy is the right, authority and obligation of the region to regulate and manage government affairs and the interests of the community on their own initiatives and aspirations.

The manifestation of the implementation of the responsibility for managing basic education by the regency/city government in Maluku is carried out in the form of regulating or establishing regional law as a legal basis for taking action to take care of or serve basic education needs. The act of regulating or establishing regional legal rules and the act of taking care of or serving the needs of basic education affairs carried out by the regency/city government in Maluku is a manifestation of the state functions as a provider and regulator as Friedmann said that there are 4 (four) state functions, namely (1) the country as a Provider, the state is responsible and guarantees a minimum standard of life as a whole and provides other social security; (2) The state as a regulator, the State rules the life of the state; (3) The State as an Entrepreneur, the State runs the economic sector through state-owned enterprises and creates an atmosphere conducive to the development of business fields; (4) The State as a Umpire, the State sets standards that are fair to those engaged in the economic sector, especially between the State sector and the private sector or between certain business fields. (Romli Librayanto, 2013)

However, the implementation of state functions as a provider by the regency/city government through the act of managing or serving basic education matters has not been done properly, because the act of managing or serving basic education needs by the regency/city government in Maluku has not yet achieved the minimum education service standard set by the central government as a guide in fulfilling basic education needs services to students, as can be seen from the achievement of basic education services by local governments compared to minimum service standards in the table below:

Table 2:-Results of the achievement of basic education services in regency/city in Maluku

\begin{tabular}{|l|l|l|}
\hline No. & \multicolumn{1}{|c|}{ Minimum Service Standards } & Achievements in Maluku Regency \\
\hline 1. & $\begin{array}{l}\text { There are educational unit within reasonable walking distance is a } \\
\text { maximum of 3 km to the ES/MI and 6 km for JHS/MTs of } \\
\text { permanent settlement groups in remote areas. }\end{array}$ & $\begin{array}{l}\text { For ES/MI it reaches 89,37\%, while } \\
\text { for JHS/MTs it reaches 50\%. }\end{array}$ \\
\hline 2. & $\begin{array}{l}\text { The number of students in each study group for ES/MI does not } \\
\text { exceed 32 people, and for JHS/MTs does not exceed 36 people. } \\
\text { For each study group there is 1 (one) class room equipped with } \\
\text { enough tables and chairs for students and teachers, as well as a a } \\
\text { blackboard; }\end{array}$ & $\begin{array}{l}\text { For ES/MI not exceeding 32 people, } \\
\text { only reaching 89.00\%, while for } \\
\text { JHS/MTs not exceeding 36 people } \\
\text { only reached 86.27\%. }\end{array}$ \\
\hline 3. & $\begin{array}{l}\text { In each JHS and MTs there is a science laboratory room equipped } \\
\text { with enough tables and chairs for 36 students and at least one set } \\
\text { of science practice equipment for demonstration and } \\
\text { experimentation of students; }\end{array}$ & $\begin{array}{l}\text { ES/MI reaches 70.00\%, while for } \\
\text { JHS/MTs it is 50.02\%. }\end{array}$ \\
\hline 4. & $\begin{array}{l}\text { In each ES/MI and JHS/MTs there is one teacher room equipped } \\
\text { with tables and chairs for each teacher, principal and other } \\
\text { education staff; and in each JHS/MTs there is a headmaster's room }\end{array}$ & $\begin{array}{l}\text { ES/MI is reached 70\%, and JHS is } \\
\text { reached 50\%. }\end{array}$ \\
\hline
\end{tabular}




\begin{tabular}{|c|c|c|}
\hline & separate from the teacher's room. & \\
\hline 5. & $\begin{array}{l}\text { In each ES/MI there are } 1 \text { (one) teacher for every } 32 \text { students and } \\
6 \text { (six) teachers for each education unit, and for special regions } 4 \\
\text { (four) teachers each education unit; }\end{array}$ & ES/MI only reaches $49.50 \%$. \\
\hline 6. & $\begin{array}{l}\text { In each JHS/MTs there is } 1 \text { (one) teacher available for each } \\
\text { subjects, and for special regions there is one teacher for each } \\
\text { family of subjects; }\end{array}$ & Only reached $50 \%$. \\
\hline 7. & $\begin{array}{l}\text { In each ES/MI there are } 2 \text { (two) teachers who meet the academic } \\
\text { qualifications of S } 1 \text { or D-IV and } 2 \text { (two) teachers who already } \\
\text { have an educator certificate; }\end{array}$ & Only reached $49,80 \%$. \\
\hline 8. & $\begin{array}{l}\text { In each JHS/MTs there are } 70 \% \text { of teachers with S-1 or D-IV } \\
\text { academic qualifications and half of them ( } 35 \% \text { of all teachers) } \\
\text { already have an educator certificate, for special areas of } 40 \% \text { and } \\
20 \% \text { respectively; }\end{array}$ & Only reached $45,60 \%$. \\
\hline 9. & $\begin{array}{l}\text { In each JHS/MTs there are teachers with academic qualifications } \\
\text { S- } 1 \text { or D-IV and already have an educator certificate for each one } \\
\text { for Mathematics, Science, Indonesian and English; }\end{array}$ & Only reached $49,63 \%$. \\
\hline 10 . & $\begin{array}{l}\text { In each regency/city, all ES/MI heads are academically qualified } \\
\text { S- } 1 \text { or D-IV and have an educator certificate; }\end{array}$ & Only reached $50 \%$. \\
\hline 11. & $\begin{array}{l}\text { In each regency/city, all heads of JHS/MTs are academically } \\
\text { qualified S- } 1 \text { or D-IV and have an educator certificate; }\end{array}$ & Only reached $50 \%$. \\
\hline 12. & $\begin{array}{l}\text { In each regency/city, all school and Madrasah supervisors have a } \\
\text { bachelor or D-IV academic qualification and have an educator } \\
\text { certificate; }\end{array}$ & Only reached $46.61 \%$. \\
\hline 13. & $\begin{array}{l}\text { regency/city, governments have plans and carry out activities to } \\
\text { assist education units in developing effective curricula and } \\
\text { learning processes. }\end{array}$ & Only reached $23,33 \%$ \\
\hline 14. & $\begin{array}{l}\text { The supervisor's visit to the education unit is conducted once } \\
\text { every month and each visit is carried out for } 3 \text { hours to conduct } \\
\text { supervision and guidance. }\end{array}$ & Only reached $80 \%$ \\
\hline
\end{tabular}

Source: Minister of National Education Regulation No. 15 of 2010 concerning Basic Education Minimum Service Standards in regencies/cities, as amended by Minister of Education and Culture Regulation No. 32 of 2018 concerning Technical Standards for Minimal Education Services, as well as Minimum Service Outcomes in Basic Education in Regency/city in Maluku.

The table above shows that the results of the achievement of basic education services in regencies/cities in Maluku have not yet reached the minimum standard of basic education services. Even the results of the Ombudsman's Republic of Indonesia research regarding compliance with public service standards related to education, health, in 33 Provinces on December 16, 2015, put Maluku Province as one of the 12 Provinces to get the lowest and worst scores in Indonesia. (Tribun Maluku, 2017)

The implementation of the act of managing or serving basic education needs by the regency/city government in Maluku must achieve a minimum service standard set by the central government as a consequence of the designation of the State of Indonesia as a unitary State. In a unitary state all governmental power is held by the central government. Government affairs including education affairs which are regulated and managed by the regions are delegations from the central government and their implementation by regional governments must be in accordance with the norms, standards and procedures set by the central government.

If the regency/city government takes care of or serves basic education affairs, the minimum service standard will affect the achievement of national education standards, because minimum service standards are the minimum limit for fulfilling the standards of content, process, competency of graduates, educators and education staff, facilities and infrastructure. Management, financing, and assessment of education that must be met by each school at the level of basic education and the achievement of national education development targets. 
The content standard concerns the material scope and level of competence as outlined in the criteria regarding graduate competencies, study material competencies, subject competencies, and learning syllabus. The standard process involves the implementation of learning to achieve graduate competency standards. Graduates 'competence standards regarding the qualifications of graduates' abilities include attitudes, knowledge, and skills. The standard of educators and education personnel concerns the criteria of education and physical and mental feasibility, as well as education in office. The standard of facilities and infrastructure involves minimal criteria regarding study rooms, sports venues, places of worship, libraries, laboratories, workshops, playgrounds, places for creation and recreation, as well as other learning resources needed to support the learning process, including the use of information and communication technology. Management standards concern the planning, implementation and supervision of educational activities. The financing standard concerns the components and the magnitude of the educational unit operating costs that are valid for one year, and the educational assessment standard concerns the mechanisms, procedures, and instruments for evaluating student learning outcomes.

National education standards as mentioned are the basis for local governments in planning, implementing or monitoring basic education programs in the regions. However, the results of evaluating the application of national education standards throughout the Province of Indonesia, placing Maluku Province below the national standard average, by obtaining ranking between 21-30 of 33 Provinces which are detailed as follows (1) graduate competency standards are ranked 24. (2) standard content is in rank 21; (3) process standards are in rank 23; (4) the standard of educators and education staff is ranked 26; (5) the standard of facilities and infrastructure is ranked 26; (6) management standards are ranked 26; (7) financing standards are in rank 30; (8) assessment standards are in rank 23. (Maluku Regional Development Planning Agency, 2018).

Such conditions indicate that basic education services in Maluku have not met national education standards, so that there are still gaps in facilities and infrastructure as well as teachers and education staff in schools in the regions that are the center of regency/city government with rural areas far from government centers, such as Jhon Rahantoknam, Deputy Chair of D Commission of the Maluku Provincial DPRD, said that in terms of the availability of educational infrastructure in areas in Maluku Province there are still many schools that do not meet national education standards especially in sub-districts or areas far from the city center. Many schools in the region, do not yet have adequate library facilities, laboratory space to computer equipment that are almost nonexistent, and from the availability of teachers, schools that are far from the central government, the number and quality of teachers is very minimal compared with schools in provincial capitals and regencies/cities (Jhon Rahantoknam, 2018). Likewise said by Minister of Education and Culture Muhadjir Effendy on February 23, 2017 when delivering socialization of education quality assurance in Maluku Province, that Maluku became a priority Province in the quality and quality education equalization program, because forty percent of elementary schools did not have libraries, and about six forty percent do not have proper toilets and there is still a shortage of teachers in schools. (Muhadjir Effendy, 2017).

While the implementation of state functions as a provider by the regency/city regional government in Maluku in the field of basic education is realized through the establishment and establishment of regional law in the field of basic education in the form of Regional Regulations or Regulations of Head of Regents/Mayors as a basis for implementing basic education needs in the regions. However, the implementation of the said function has not been fully carried out by the regency/city government, as stated by M. Tuakia the head of the legal department of the Maluku Tengah regency that until now the Maluku Tengah regency government has not established or established regional regulations or regent regulations governing the implementation of education base in Maluku Tengah Regency. The implementation of basic education in the Maluku Tengah regency proposes or is based on ministerial regulations, government regulations and laws.

Similar conditions also occur in the Aru Islands regency, as stated by Novy Edwin M. Solissa, the head of the legal department of the Aru Islands regency government that until now the Aru Islands regency government has not stipulated regional regulations or regent regulations governing the implementation of basic education affairs. The implementation of basic education in Aru Island regency refers to the legislation in the field of education set by the central government. For the city of Ambon, according to the Chief of Law Section S. Slarmanat, the Ambon regional government has set several Ambon city regulations and Mayor Regulations relating to basic education in Ambon city, including Ambon City Regional Regulation No. 5 of 2010 concerning the Implementation of Education in Ambon City, Ambon Mayor Regulation No. 2 of 2010 concerning Mandatory Local Content in the Education Unit Curriculum, Ambon Mayor Regulation No. 10 of 2013 concerning the Development and Professional 
Development of Educators and Education Personnel, and Mayor of Ambon Regulation No. 26 of 2014 concerning the Implementation of Inclusive Education in Regular Schools.

The conditions as stated show that the regency/city governments in Maluku generally have not implemented the functions of the state as regulators through the establishment of local legal rules as appropriate. Even though the function of regional legal products is part of regional policy to carry out basic education affairs that are submitted to the regions. Regional regulations and regional head regulations in the field of basic education made and established by the regency/city government in Maluku as a system of organizational control in managing basic education in each region.

In principle, the implementation of state functions as a provider and regulator in the field of basic education by the regency/city government in Maluku as a manifestation of the position of ruler and servant. In the position of ruler, the regency/city government makes regional law in the field of basic education which guides the implementation of basic education in the regions must be obeyed by all elements in the region, while in the position of servants, the regency/city government provides basic education services to community members.

Implementation of the function is intended both in the field of provision of facilities and infrastructure, provision of teachers and education staff as well as basic education funding so as to be able to direct and control basic education by focusing on quality to produce inputs, processes, outputs and outcomes in developing quality basic education systems in Maluku as consequently giving authority to the regions to regulate and manage government affairs by giving autonomy to the regions, as said by Agussalim Andi Gadjong that the transfer of government affairs to the regions was accompanied by the transfer of funding, facilities and infrastructure, and human resources in accordance with the authority submitted. (Agussalim Andi Gadjong, 2007). This as a manifestation of regional independence in regulating and managing government affairs submitted is a matter of regional household affairs, because the nature of the surrender of basic education affairs to the regency/city as an effort to improve the implementation of government duties in the field of basic education in regions that minimize basic education bureaucracy which is less aspiration and makes regency/city areas in Maluku an independent unit in carrying out the responsibility of regulating and managing basic education affairs through the implementation of responsibilities regulating or forming and stipulating regional regulations and regional head regulations in the field of basic education and managing or serving education implementation needs the basis of each region to build a basic education system as a means of providing and providing provisions for every citizen in Maluku to obtain quality basic education.

\section{Conclusion:-}

The central government has delegated basic education affairs to regency/city areas including in Maluku Province which is normatively determined in article 50 sections (5) of Law No. 20 of 2003 concerning the National Education System, in conjunction with article 12 section (1) and Attachment to Law No. 23 of 2014 concerning Regional Government. The devolution of basic education matters referred to local governments bore responsibility Regency/city in Maluku to carry out government actions in the field of basic education. The manifestation of the implementation of the responsibilities of the Regency/city government in Maluku in managing basic education is carried out through the act of regulating and establishing and regulating regional law in the form of regional regulations and regional head regulations in the field of basic education, and the act of managing or serving basic education needs.

However, the regency/city government has not carried out the action of managing or serving basic education matters in accordance with the minimum education service standard. Likewise, the regency/city governments have not yet implemented measures to regulate or establish both regional regulations and regional head regulations as a manifestation of the implementation of state functions as a provider which should be the basis for action law for basic education services in Maluku. The implementation of the responsibilities referred to by the regency/city government in Maluku is also a manifestation of the implementation of regional authority in regulating and managing self-government affairs as an autonomous government unit. 


\section{References:-}

1. Agussalim Andi Gadjon, 2007, Local Government Studies Politics and Law, Ghalia Indonesia, Bogor Maluku Regional Development Planning Agency, 2018

2. Central Statistics Agency, 2018

3. National Development Planning Agency, 2018

4. Maluku Province Planning Agency, 2018

5. Diding Nurdin, 2015, Education Management from Theory to Implementation, RajaGrafindo Persada, Jakarta.

6. H. M. Hasbullah, Educational Policy in The Theory, Application and Objective Conditions of Education in Indonesia, RajaGrafindo Persada, 2016, Jakarta.

7. Second Year Report Quality of School Education in Maluku, Collaboration between Maluku Regional Development Planning Agency and Faculty of Teacher Training and Education Pattimura University, 2016, Ambon.

8. Romli Librayanto, 2013, State Science an Introduction, Arus Timur, Makassar.

9. Submission of Material Socialization of Quality Assurance in Maluku Province by Muhadjir Effendy, Minister of National Education of The Republic of Indonesia on February 23, 2017, Ambon, Maluku Province.

10. Media TRIBUN Maluku.com, Accessed on February 20, 20181945 Constitution of The Republic of Indonesia

11. Indonesia State Law No. 20 of 2003 Concerning The National Education System

12. Indonesia State Law No. 23 of 2014 Concerning Local Government

13. Minister of National Education Regulation No. 15 of 2010 concerning Basic Education Minimum Service Standards in regencies/cities, as amended by Minister of Education and Culture Regulation No. 32 of 2018 concerning Technical Standards for Minimal Education Services, as well as Minimum Service Outcomes in Basic Education in Regency/city in Maluku.

14. Interview with Jhon Rahantoknam, Vice Chairman of Commission D of DPRD Maluku Province, in Maluku Provincial Parliament Building, March 19, 2018

15. Interview with M. Tuakia, Head of Division Maluku Tengah Regency Government Law, 2018.

16. Interview with Novy Edwin M. Solissa, Head of Division Aru Island Regency Government Law, 2018.

17. Interview with S. Slarmanat, Head of Division Ambon City Government Law, 2018. 